\title{
PELATIHAN PENGGUNAAN APLIKASI DAN SISTEM INFORMASI PENERIMAAN PESERTA DIDIK BARU (PPDB) ONLINE DI SMA NEGERI 1 BARABAI
}

\author{
Yusri Ikhwani, Muhammad Hasbi, dan Andie \\ Fakultas Teknologi Informasi, Universitas Islam Kalimantan MAB \\ E-mail :yusri.ikhwani@gmail.com
}

\begin{abstract}
SMA Negeri 1 Barabai is one of the establishments engaged in education requires a source of data and proper data processing in order to create efficiency and accuracy of data that can support operational processes, management and decision-making process with good and proper. Good data processing system makes the information that goes to support all existing activities in agencies or companies.

Admission Process Students New (PPDB) in SMA Negeri 1 Barabai for this system used still manual that prospective students in the registration process to enter data by writing on the registration form after the data is written on the registration form, and then recapitulated by the committee PPDB into computer. In the process of data recap this committee is only using Microsoft Excel software in processing the data and not use an information system, because the number of applicants who pretty much is about 900 applicants, so that in the process and if the data input takes quite a bit. Because not everyone can mengguaan application, then conducted training for the use of applications and information systems PPDB this.
\end{abstract}

Keywords: PPDB, online, school

\section{PENDAHULUAN}

Seiring perkembangan teknologi yang semakin pesat mempengaruhi suatu sistem dan efisiensi operasional dalam dunia kerja. Di abad sekarang ini dibutuhkan fasilitas-fasilitas yang memadai untuk pengembangan usaha guna mencapai tujuan meningkatkan pelayanan pada masyarakat. Dalam hal ini salah satunya adalah penggunaan sistem komputerisasi yang diterapkan dalam dunia kerja, penggunaan sistem komputerisasi selain mempermudah dalam hal pengolahan data, juga membuat proses kinerja lebih efektif dan efisien.

SMA Negeri 1 Barabai merupakan salah satu instansi yang bergerak di bidang pendidikan membutuhkan sumber data dan pengolah data yang tepat agar tercipta efisiensi dan keakuratan data yang dapat mendukung proses operasional, menejemen dan proses pengambilan keputusan dengan baik dan tepat. Sistem pengolah data yang baik membuat informasi yang masuk dapat menunjang semua kegiatan 
yang ada di instansi atau perusahaan tersebut.

Proses Penerimaan Peserta Didik Baru (PPDB) di SMA Negeri 1 Barabai selama ini sistem yang digunakan masih bersifat manual yaitu para calon siswa dalam proses registrasi memasukkan data dengan menulis pada formulir pendaftaran setelah data yang ditulis pada formulir pendaftaran, baru kemudian direkap oleh panitia PPDB kedalam komputer. Dalam proses rekap data ini panitia hanya menggunakan software microsoft Excel dalam mengolah data dan belum menggunakan sebuah sistem informasi, karena jumlah pendaftar yang cukup banyak yaitu sekitar 900 pendaftar, sehingga dalam proses input dan olah data membutuhkan waktu yang tidak sedikit. Karena tidak semua orang bisa mengguaan aplikasi, maka dilakukan pelatihan untuk penggunaan aplikasi dan sistem informasi PPDB ini.

\section{KHALAYAK SASARAN}

Panitia Penerimaan Peserta Didik Baru (PPDB) di SMA Negeri 1 Barabai juga merupakan guru atau pengajar disekolah tersebut. Panitia terdiri dari 1 ketua dan 4 anggota, tugas masing-masing mulai dari penyebaran selebaran, peoses pendaftaran, pendataan, persiapan tes, penyaringan calon siswa baru sampai akhirnya pengumuman kelulusan calon siswa baru. Yang setiap proses pada awalnya dilakukan secara manual.

Setelah aplikasi dan sistem informasi penerimaan peserta didik baru (PPDB) selesai, maka tugas selanjutnya adalah bagaimana mengajarkan cara menggunakan aplikasi tersebut dengan baik dan benar, mulai dari proses login admin, input data pendaftaran, pengelolaan data sampai proses print out data dan laporan.

\section{METODE}

Untuk mencapai tujuan yang diharapkan, maka pelaksanaan pelatihan penggunaan aplikasi ini menggunakan 3 metode, yaitu:

\section{Tutorial}

Instruktur menjelaskan tentang tata cara penggunaan aplikasi dengan menggunakan alat bantu LCD sehingga peserta dapat memahami tanpa harus mendengarkan teori atau membaca modul terlebih dulu.

\section{Praktek Mandiri}

Setiap peserta melakukan praktek menggunakan aplikasi mulai dari proses login admin, input data pendaftaran, 
pengelolaan data sampai proses print out data dan laporan.

Tanya Jawab

Peserta dapat langsung bertanya kepada Tim Pengabdian pada masyarakat yang mendampingi mereka selama kegiatan berlangsung.

\section{HASIL DAN PEMBAHASAN}

Selama pelaksanaan kegiatan peserta sangat antusias, karena selama ini mereka belum pernah menggunakan aplikasi PPDB sebagai sarana prasarana dalam penerimaan siswa baru, bahkan ada guru yang minta diajarkan pembuatan aplikasi secara singkat. Dari hasil kegiatan yang telah dilaksanakan, seluruh peserta yang hadir mampu menggunakan aplikasi dengan mudah, karena design aplikasi sudah dirancang untuk digunakan oleh orang awam sekalipun.

\section{FOTO KEGIATAN}
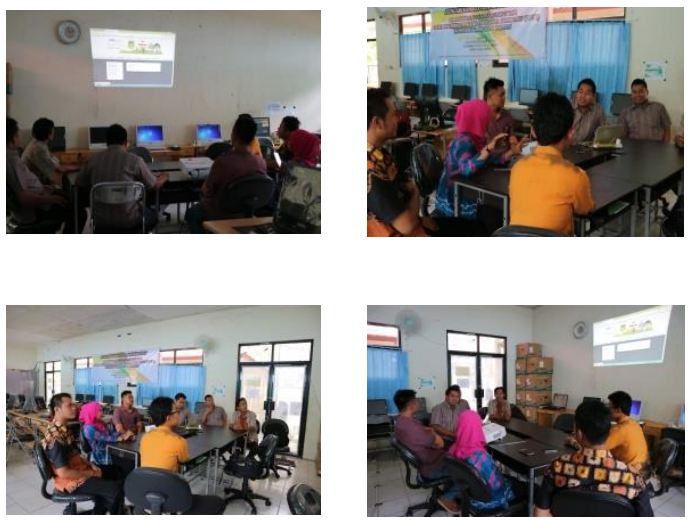
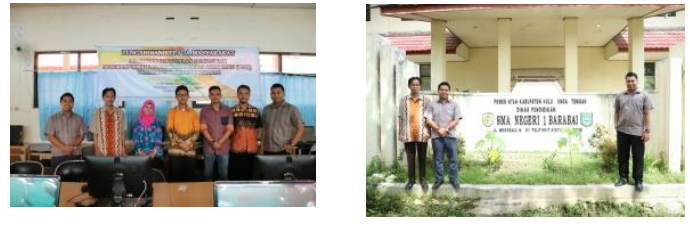

\section{KESIMPULAN}

Untuk mencapai tujuan yang diharapkan, maka pelaksanaan pelatihan penggunaan aplikasi ini menggunakan 3 metode, yaitu tutorial, praktek mandiri dan tanya jawab. Selama pelaksanaan kegiatan peserta sangat antusias, karena selama ini mereka belum pernah menggunakan aplikasi PPDB sebagai sarana prasarana dalam penerimaan siswa baru, bahkan ada guru yang minta diajarkan pembuatan aplikasi secara singkat. Dari hasil kegiatan yang telah dilaksanakan, seluruh peserta yang hadir mampu menggunakan aplikasi dengan mudah, karena design aplikasi sudah dirancang untuk digunakan oleh orang awam sekalipun.

\section{DAFTAR PUSTAKA}

Ferdinand, M. (n.d.). Sistem Informasi. Retrieved April 18, 2015, from http://apr11-si.comuf.com/SI.pdf

Hakim, Z. (2012, Agustus 16). Apa Itu Pemrograman Web? Retrieved April 2016, 28, from Pemrograman Web: http://www.zainalhakim.web.id/p osting/apa-itu-pemrogramanweb.html 
Kasiman, P. (2009). Aplikasi Web dengan PHP dan MySQL. Yogyakarta: ANDI.

Martin, J. (1990). Information Enginnering : Book II Planning and Analysis. 2nd Edition. New Jersey: Prantice-Hall. Inc.

Peranginangin, K. (2006). Aplikasi $W E B$ dengan PHP dan MySQL. Yogyakarta: ANDI.

Permana, B., \& dkk. (2011). Aplikasi Pengolahan Data Produksi Berbasis Web Di PT. Telehouse
Engineering. Bandung: JBPTUNIKOMPP.

Subekti, M. (1997). Sistem manajemen Basis Data. Jakarta: Universitas Bina Nusantara.

Wikipedia. (2016, April 8). HTML. Retrieved April 22, 2016, from Wikipedia: http://id.wikipedia.org/wiki/HTM $\mathrm{L}$

Wikipedia. (2016, Januari 3). PHP. Retrieved April 22, 2016, from Wikipedia: http://id.wikipedia.org/wiki/PHP 